\title{
The superb Brazilian Fortresses of Macapá and Príncipe da Beira
}

\author{
João Campos \\ Centro de Estudos de Arquitectura Militar de Almeida, Almeida, Portugal, arch.jcampos@gmail.com
}

\begin{abstract}
During the eighteenth century Portugal developed a large military construction process in the Ultramarine possessions, in order to compete with the new born colonial trading empires, mainly Great Britain, Netherlands and France. The Portuguese colonial seashores of the Atlantic Ocean (since the middle of the sixteenth century) and of the Indian Ocean (from the end of the first quarter of the seventeenth century) were repeatedly coveted, and the huge Portuguese colony of Brazil was also harassed in the south during the eighteenth century -here due to problems in a diplomatic and military dispute with Spain, related with the global frontiers' design of the Iberian colonies.

The Treaty of Madrid (1750) had specifically abrogated the Treaty of Tordesillas (1494) between Portugal and Spain, and the limits of Brazil began to be defined on the field. Macapá is situated in the western branch of Amazonas delta, in the singular cross-point of the Equator with Tordesillas Meridian, and the construction of a big fortress began in the year of 1764 under direction of Enrico Antonio Galluzzi, an Italian engineer contracted by Portuguese administration to the Commission of Delimitation, which arrived in Brazil in 1753.

In consequence of the political panorama in Europe after the Seven Years War (1756-1763), a new agreement between Portugal and Spain was negotiated (after the regional conflict in South America), achieved to the Treaty of San Idefonso (1777), which warranted the integration of the Amazonas basin. It was strategic the decision to build, one year before, the huge fortress of Príncipe da Beira, arduously realized in the most interior of the sub-continent, $2000 \mathrm{~km}$ from the sea throughout the only possible connection by rivers navigation. Domingos Sambucetti, another Italian engineer, was the designer and conductor of the jobs held on the right bank of Guaporé River, future frontier's line with Bolivia.

São José de Macapá and Príncipe da Beira are two big fortresses Vauban’ style, built under very similar projects by two Italian engineers (each one dead with malaria in the course of building), with the oservance of the most exigent rules of the treaties of military architecture.
\end{abstract}

Keywords: Vauban’ style, Limits of Brazil, São José de Macapá, Príncipe da Beira.

\section{Introduction}

The continental dimensions of Brazil are the result of a slow process of expansion, occurring over centuries. The construction of fortresses functioned largely to consolidate future occupation strategies of these vast geographical areas. The main set of locations was delimited by Fortresses Príncipe da Beira and Coimbra, as land- marks on the western border; Macapá (with Belém do Pará), as a mark of the northern border; the set of forts on the island of Santa Catarina, in the southern division; and marking the extreme eastern borders, the Fort of Reis Magos / Natal, and Santa Catarina / Cabedelo. In turn, the strongholds of Bahía-de-Todos-os-Santos (Mon- 
te Serrat, Santa Maria, São Diogo and Santo Antônio da Barra) and Baía da Guanabara (Santa Cruz and São João) marks the defenses of the two capitals of colonial Brazil, Salvador and Rio de Janeiro. Finally, the forts of Barra de Santos, including the Canal de Bertioga forts (Barra Grande and São João), point to the defense of the port that drained most of the wealth produced in Brazil and, therefore, endowed with a fortresses system built from sixteenth century to the early nineteenth century. The whole system forms one of the largest defensive sets in the world, with continental dimensions, covering an area of $8500000 \mathrm{~km}^{2}$ and $23000 \mathrm{~km}$ of borders.

\section{The meridian of Tordesillas' Treaty and the border line of Brazil}

In the following figure we note the three more important fortifications to the left side of Tordesillas' Treaty line (São José de Macapá, Príncipe da Beira and Coimbra) which represent the huge effort of Portugal to acquire a large possession of territory with geographical unity. Portuguese rulers preferred to maintain the basins of the rivers with integrity, so their efforts were directed to the Amazonas River. Here lay the two larger military constructions from colonial times in all South America, and the most qualified Vauban' type fortifications outside Europe.

By the Treaty of Madrid (1750) the Treaty of Tordesillas was revoked. From that moment on, and having been acquired that it would be at the negotiating table that the borders between Portugal and Spain would be defined, the Portuguese strategy of expanding the ownership of the territory beyond the international line is completely noticeable. This strategy results in the foundation of the town of Macapá (1751), at the mouth of the Amazonas River and, a few years later, that of Mazagão (1770).

With a view to defining a frontier, in the first half of the eighteenth century Portugal build, based on a vast river axis, a strategic military, political and commercial line to maintain dominance of the Amazonas region. Along the great Rivers Amazonas, Madeira and Guaporé, several fortifications (Almerim, Santarém, Óbidos, Manaus, etc.) were built, while insisting on the set- tlement of the far north, in the delta region (Belém, Macapá, Chaves, Mazagão, etc.).

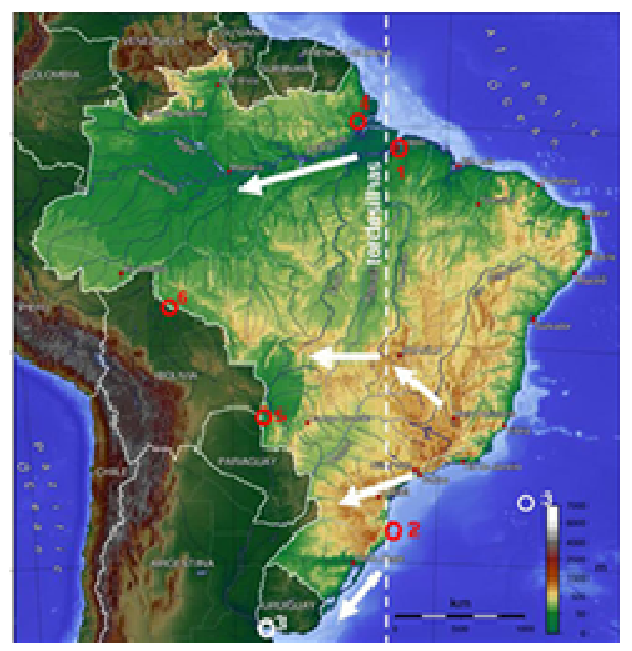

Fig. 1. Forts \& expansion axes. Forts: 1) Castelo (before named Presépio), Belém do Pará, 1616; 2) Santa Catarina Defense System (with 7 fortifications to the strategical dispute of the southern Border), Santa Catarina, 1739; 3) Colónia do Sacramento, Uruguay, 1680 (and left by Madrid and Santo Ildefonso Treaties, 1750-1777); 4) São José, Macapá, 1764; 5) COIMBRA, Corumbá, 1775; 6) Príncipe da Beira, Rondónia, 1776. Expansion Axes: north) River Amazonas Bassin; south) River Plata Bassin; southwest) Índians (Spanish Jesuits); center) Mining (gold, diamonds) (Author).

The occupation plan was complemented by the installation in the second half of the eighteenth century of new modern fortresses. The starting point was São José Fortress, in Macapá, and at the far end of the line, to the southwest, another fortification of a similar size, on the banks of the Guaporé River, the Royal Fort of Príncipe da Beira, built near the site of a previous and small defensive work, Fort Bragança.

The building plan was implemented and, although the economic outcome of the trade route was not consolidated, it fully served the political objectives, expressed in the expanded expression of the huge frontier that deepened into the interior American subcontinent. It results, as an heritage, the two largest fortifications built in colonial Brazil: São José de Macapá and Príncipe da Beira, two quadrilaterals with regular pentagons at the angles, within the purest canonic regularity of the bulwarked principles. 

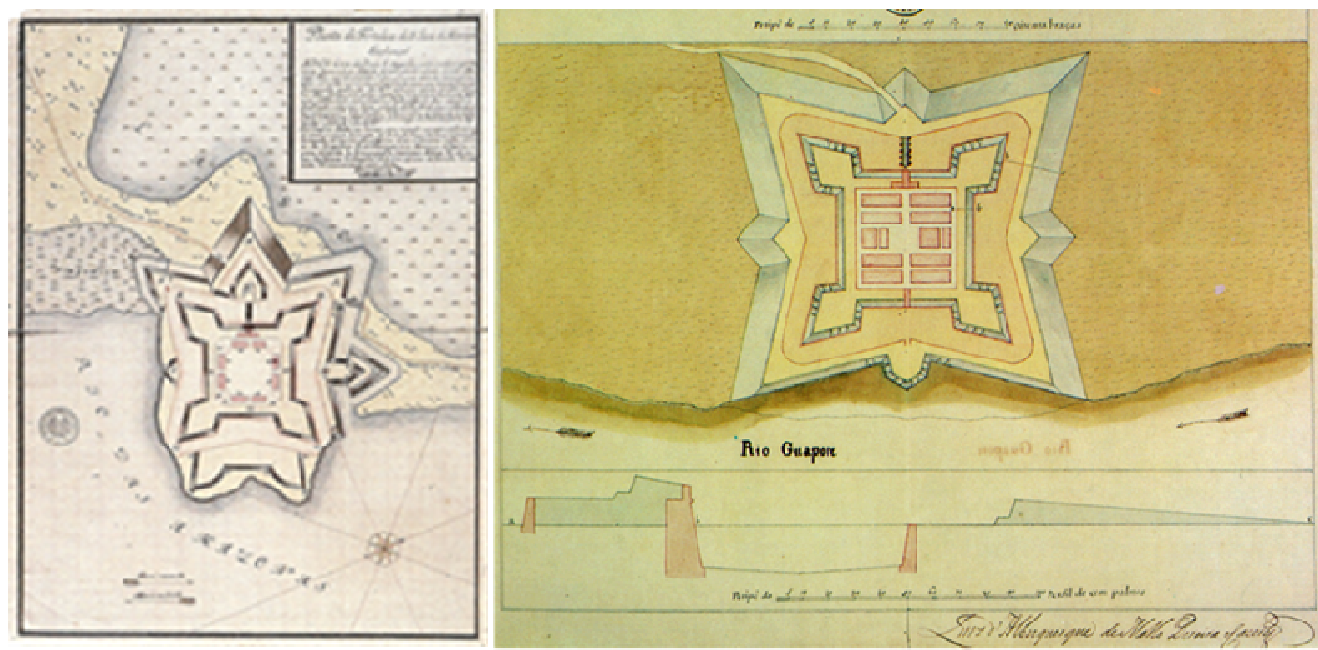

Fig. 2. "Planta da Fortaleza de S. Jozé de Macapá". Desenho a bico de pena, s.a., s.d. [séc. XVIII), Arquivo Militar do Rio de Janeiro. Source: Digital Archives of IPHAN, Rio de Janeiro, Brazil.

Two centuries later (1950) both fortifications were recognized as national heritage. Today they embody the Brazilian Indicative List (since January 2015) for the declaration of the "Brazilian Fortifications Ensemble" as World Heritage.

The most substantial differences between the two fortresses are in terms of exterior works and the organization of the relationship with the waterfronts. The traces of a French school are very clear, although both projects were led by Italian engineers. It was already a time of affirmation of the bulwarked building as the great international architecture, offering principles adapted to the conditions of its exportation to new continents.
Fig. 3. "Real Forte do Príncipe da Beira - Projecto do Quadrado Regular em $q$ ha de consistir a nova Fortaleza [...] sobre a Margem direita do Rio Guapore [...]" (ca. 1775). Author: Domingos Sambucetti (attributed). Source: Arquivo Histórico do Exército, Rio de Janeiro, Brazil. The original is signed by Luiz Albuquerque de Mello Pereira e Cáceres, Governor of the State of Mato Grosso, than created in the region by the Portuguese Prime-minister, Marquis of Pombal.

\section{Brief Characterization}

The fortresses São José de Macapá and Príncipe da Beira are, perhaps, the largest constructions that express, worldwide, by their dimensions and the rigor of the execution according to the rules of the architectural treaties, the functional sense of the bulwarked fortification adapted in any circumstance, either in Europe or in overseas spaces.
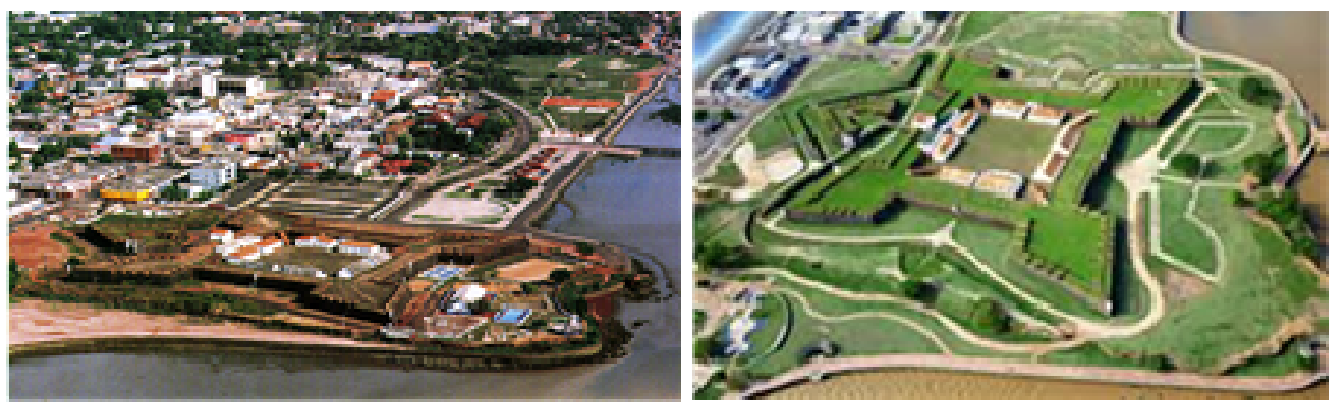

Figs. 4 and 5. Aerial general view and new landscaping of the fortress of São José de Macapá. 

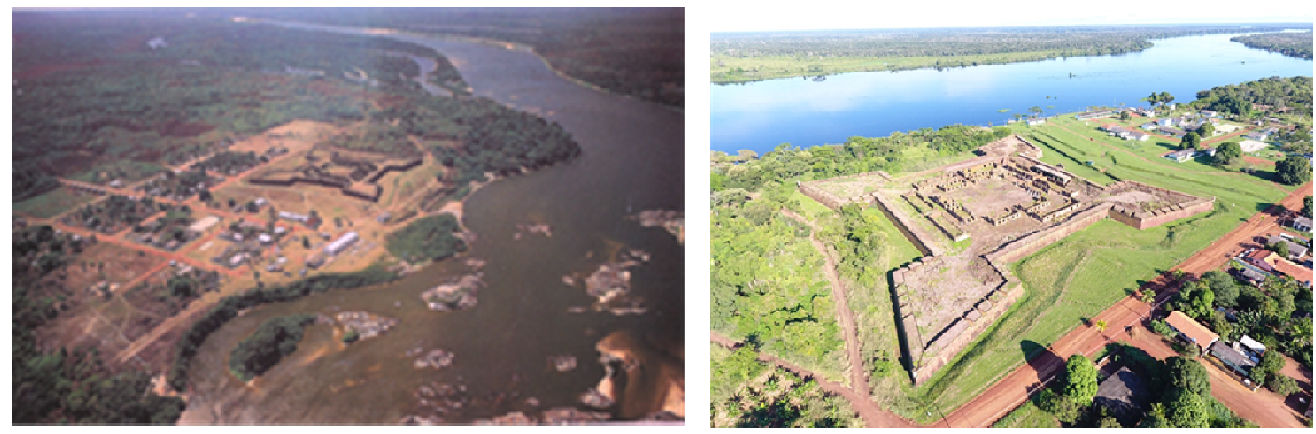

Figs. 6 and 7. Aerial general view and situation of the fortress of Príncipe da Beira, in the border with Bolivia (Guaporé River).

São José de Macapá / AP $\left(0^{\circ} 1^{\prime} 50.60^{\prime} \mathrm{N}, 51^{\circ}\right.$ 2'57.77" W) was built on the northern bank of the Amazonas River, where Irish and British had set up trading posts in the early seventeenth century. After the destruction of these occupations and the construction, on the same site, of a first Portuguese fort, it was destroyed by the French in 1697, claiming the territory of the north bank of the mouth of the Amazonas River.

The preserved fortress was built from 1764, and was completed by Portuguese settlers who, from the colonial Portuguese city of Mazagão (Morocco), participated in the formation of the colony established in the region (1770).
The Royal Fort of Prince of Beira $\left(12^{\circ} 25^{\prime} 40^{\prime \prime} \mathrm{S}\right.$, $\left.64^{\circ} 25^{\prime} 22^{\prime \prime} \mathrm{W}\right)$ was erected in a repeat of the basic design of the Macapá fortification in 1776, in an attempt to create a new fact and to difficult to challenge in the ongoing negotiations which, in the following year, led to the conclusion of the Treaty of Santo Ildefonso, defining Brazilian frontier.

Basic plans are similar to both fortifications. The situation initially led by Enrico Galluzzi at the delta of Amazonas River, had the participation of Domingos Sambucetti, which concluded the works after the dead of the first engineer.
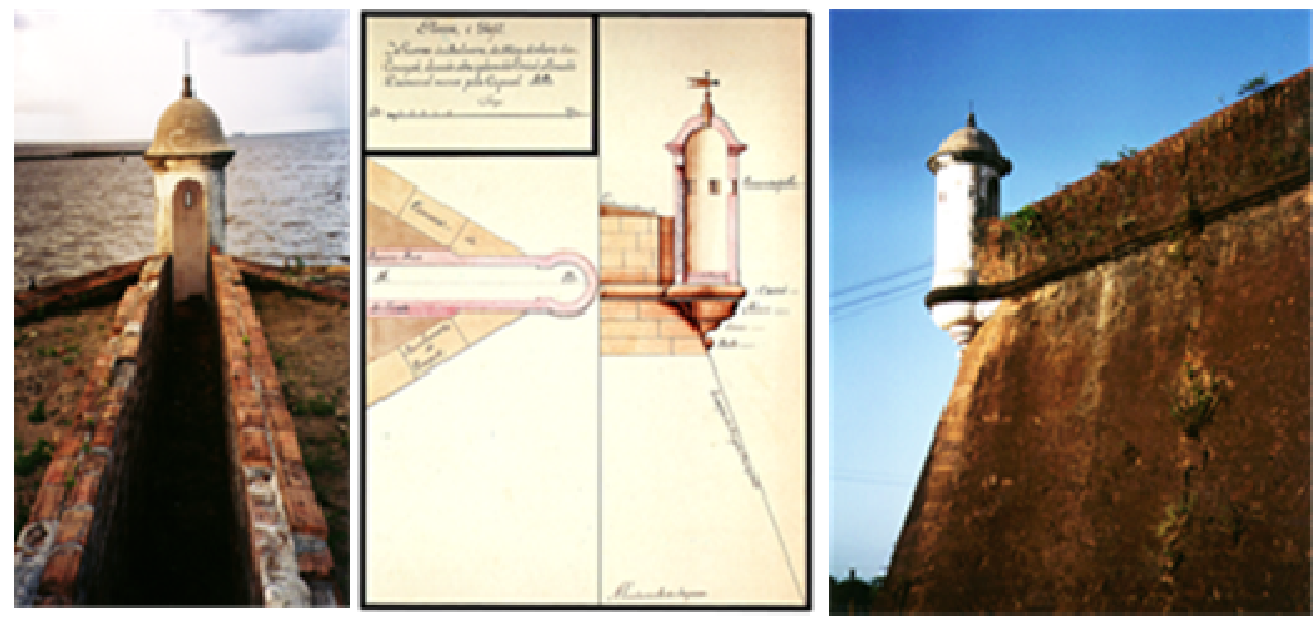

Figs. 8-10. One sentry at São José Fortress, Macapá (left), and another one at Príncipe da Beira Fortress (right). In the middle, reproduction of the drawing of the project to build the fortification at Guaporé River. 


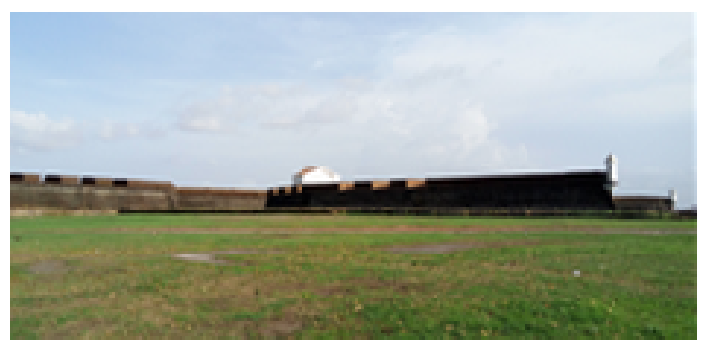

Fig. 11. General view from the waterfront side, with the sentries at the angles of the bulwarks and, at the rear, the volume of the Main Gate (land side) (Author).

Later he was appointed by Luiz de Albuquerque de Mello Pereira e Càceres, cousin of the Portuguese Prime-minister, the Marquis of Pombal, and Governor of the new Brazilian State of Mato Grosso, to the construction of Príncipe da Beira, at Guaporé River, one of the important tributaries of Amazonas.

It was a heathland, disputed by some great economic interests and where the Spanish Jesuits had established the mission of Santa Rosa.

The location was decided in a final phase of Iberian diplomatic discussions to determine the limits of Brazil. Sambucetti choose the place in 1774 and inscribed there the plan, which was sent to Lisbon in the following year.

Since 1756 the engineer got experience in the region, drawing the fortresses of Santarém, Almeirim and Gurupá (State of Grão-Pará) and assisting in the works and finalizing Macapá fortress, with Galluzzi.

There are also documents at Casa da Ínsua (Lamego / Portugal, the Family house of Luís de Albuquerque de Mello e Cáceres), with plans for the new city to settle the inhabitants of Mazagão (retreated from Morocco in a massive abandonment), arrived in Belém do Pará to create Nova Mazagão (the New Mazagan), choosing the place and tracing the urban order, near Macapá.

These people were the one who manage the construction of the fortress of São José, with an acquired knowledge how it was to live in a Modern fortification as it was Mazagão.
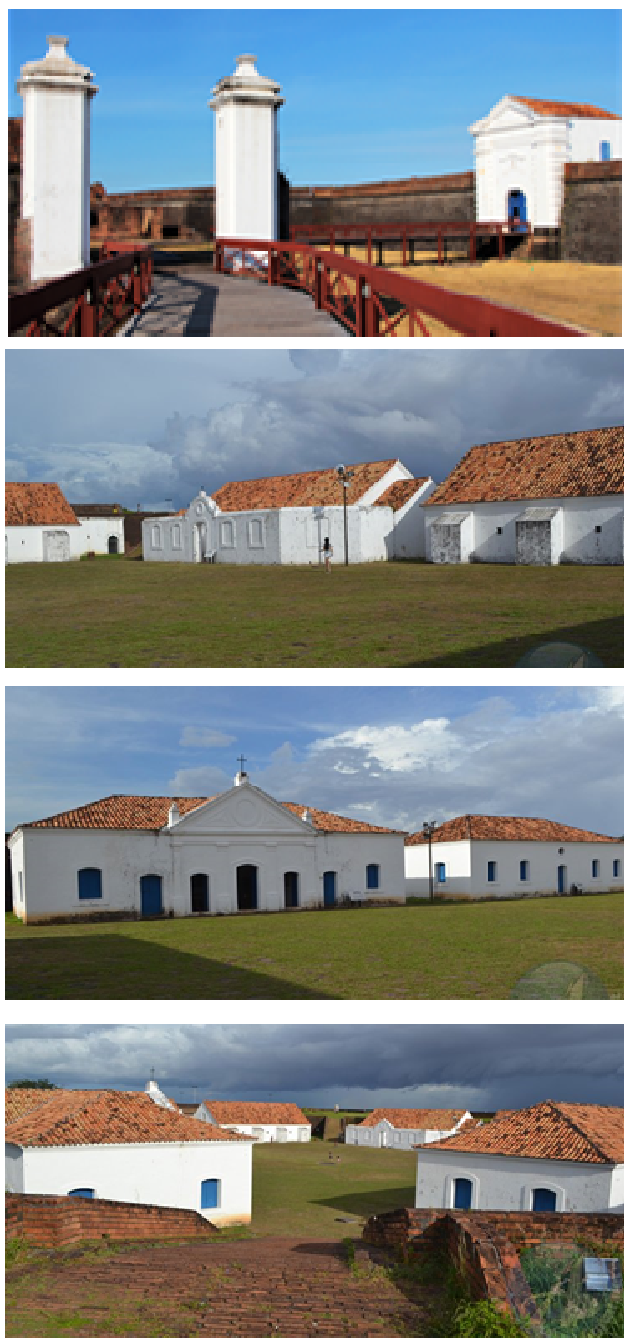

Figs. 12-15. Top - the present entrance of the fortress of São José, Macapá, from the exterior ravelin to the Main Gate in the middle of the curtain, through a wooden bridge over the ditch (Author). In the successive photos the present situation (2003) of the interior of the fortress: in the first one the magazine of powder and two other pavilions bomb-proof (for guns and food); the chapel with symmetrical compartments for troops and a barrack for officers; and a global view of the inner fortification, taken from the top of the ramp to the embankment and bastion of the fortress. 


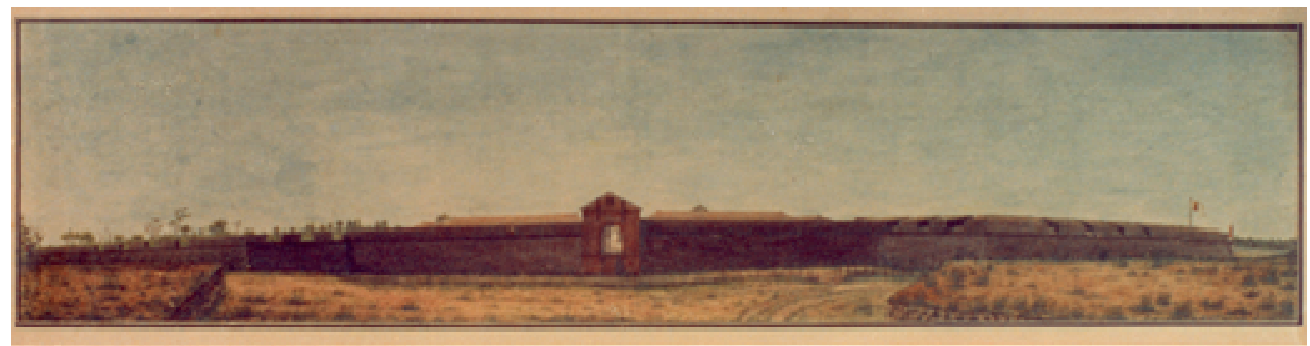

Fig. 16. View of Príncipe da Beira Fortress, drawing belonging to the Archives of Casa da Ínsua (Lamego, Portugal), author unknown, showing the general aspect of the military construction on the way to the entrance.

The fortress of Príncipe da Beira measure circa $1000 \mathrm{~m}$ of the implantation perimeter. The high of the walls is about $10 \mathrm{~m}$, and each bastion was prepared for 14 cannons. The access was by a wooden drawbridge in the north side, which of course no longer exists, but there are plans to reconstruct the way to the Main Gate (see drawing).

The interior of the fort had 14 barracks for the commander and officers, and also chapel, hospital, powder magazine and pavilions for guns and food.

That huge constructions in a no-where place, in the middle of the jungle, and without communication conditions is still today difficult to understand the big sacrifice that in mean to be realized. We can express an idea by the notice that, in 1825 were sent from Belém do Pará four bronze 24 'cannons, by Tapajós River. They arrived five years later.

\section{Strategic decisions}

The Portuguese wanted the benefits of gold mining in the region, as well as Spaniards. These ones allowed to settle Jesuit missions along the Guaporé River and its tributaries. To warrant the Portuguese sovereignty, it was built a small fort (named after Nossa Senhora da Conceição or Bragança). However the opponent forces made continuous efforts to conquer it, but due to epidemic of local diseases these actions were postponed. Later, in 1771, the fort was destroyed by the river flood. In the next year it was established the plan for a new big fortification, wich
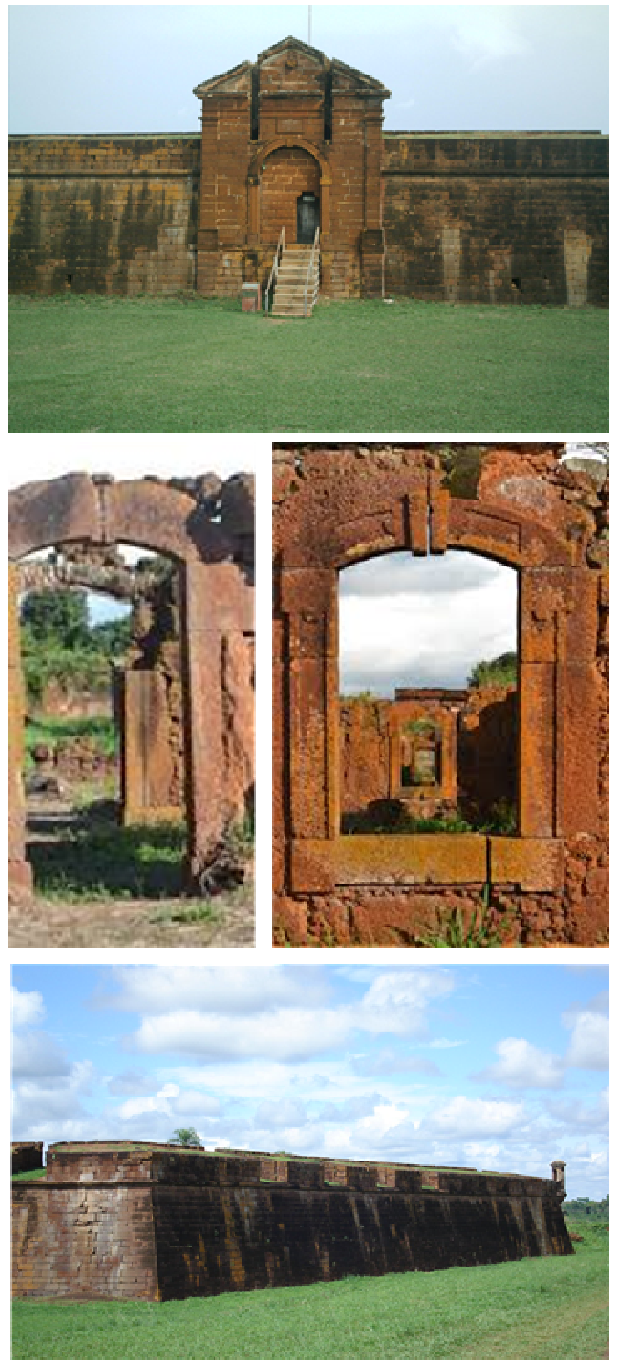

Figs. 17-20. Photos of the conserved walls and the ruins of the interior pavilions. All the built components were engulfed by the jungle, being brought to day-light in a military expedition commanded by Cândido Rondon (future President of the Republic of Brazil), 1914 (Author). 


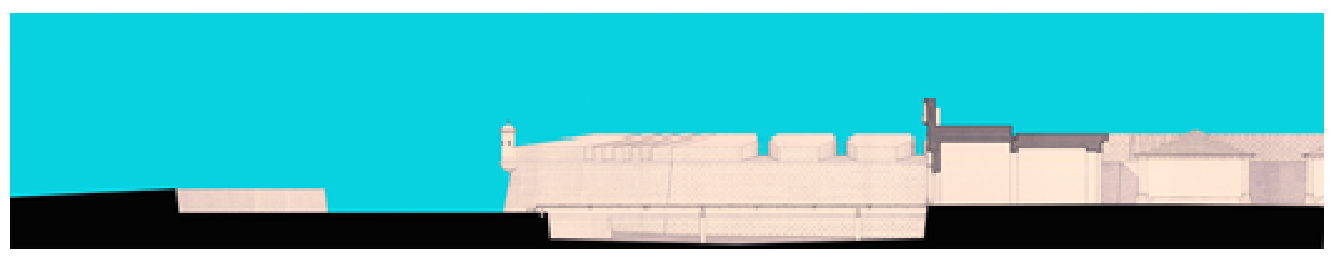

Fig. 21. Drawing of the Rehabilitation Project (1986) by Prof Arch. Alfredo Viana de Lima (1913-1991), offered to the Brazilians Authorities by Calouste Gulbenkian Foundation, in which the Author collaborated. It is a Section by the entrance axis, with the proposal of a modern bridge (concrete, iron, wood) over the ditch (not implemented, yet).

would permit to affirm the possession of the area, giving access to the mines of Guaporé and Tanquinhos (actual Mateguá, Bolivia). The drainage of goods would be made in security through Rivers Guaporé, Mamoré and Madeira, giving the monopoly to the State enterprise "Companhia Geral de Comércio do Grão-Pará e Maranhão".

At same time, that was the final argument to conclude the negotiations on the limits of Brazil, in 1777 , immediately after the beginning of the implementation of Príncipe da Beira, $2 \mathrm{~km}$ away from the point of the ancient small Fort Bragança.

\section{Bibliography}

Correia, J.R.; Corrêa, T.G.; Wright, A.F.P.A.; Stella, R.S.; Correia, D.A. (1999). Fortificações Portuguesas no Brasil, dos Descobrimentos à Época Pombalina. A fundação do sistema português de comunicação ultramarina. Uma redescoberta da origem cultural do Brasil, Monsaraz.

Dias, P. (1999). História da Arte Portuguesa no Mundo (1415-1822). O Espaço Atlântico, Lisboa.

Faria, M. (1996). "Príncipe da Beira: a fortaleza para além dos limites", Oceanos, 28, p. 54-58.

Fontana, R. (2005). As obras dos engenheiros militares Galluzzi e Sambuceti e do arquiteto Landi no Brasil colonial do século XVIII, Senado Federal, Brasília.

Garcia, J.C., coord. (2002). A mais dilatada visão do mundo. Inventário da Casa da Ínsua, Lisboa.

Iria, A. (1966). "Inventário geral da Cartografia Brasileira existente no Arquivo Histórico Ultramarino (Elementos para a publicação da Brasilae Monumenta Cartographica)", in IV Colóquio Internacional de Estudos LusoBrasileiros. Separata de Studia ${ }^{\circ} 17$, Lisboa.

Lemos, C. (1989). “O Brasil”, in História das Fortificações Portuguesas no Mundo, Lisboa, pp. 235-272.

Nunes, J.M.S. (1985). Real Forte Príncipe da Beira, Cartografia e iconografia de Isa Adonias, Fundação Emílio Odebrecht, Salvador.

Viterbo, F.M.S. (1988, facsimile 1899). Dicionário Histórico e Documental dos Arquitectos, Engenheiros e Construtores Portugueses ou a serviço de Portugal, Imprensa Nacional - Casa da Moeda, Lisboa, for Galluzzi, vol. I, pp. 407-410; for Sambucetti, vol. III, p. 7. 
